\title{
SOME ASPECTS OF THE NULLIFICATION OF GOLD CLAUSES IN OBLIGATIONS
}

The legislation recently enacted by Congress purporting to nullify the effect of gold clauses ${ }^{r}$ is of great importance to debtors and creditors. ${ }^{2}$ It provides substantially that all obligations, public and private, calling for payment in gold or a particular kind of currency, or in an amount of money measured thereby, are contrary to public policy; and that every obligation, heretofore or hereinafter incurred whether or not such a provision is contained therein, shall be discharged by the payment, dollar for dollar, in any coin or currency which at the time of payment is legal tender for public or private debts. ${ }^{3}$ The validity of this attempted nullification of the effect of gold clauses in obligations will depend directly upon the interpretation which the Supreme Court places on the gold coin stipulations as made by the parties.

A similar problem was raised shortly after the Civil War by The Legal Tender Act, ${ }^{4}$ whereby the Union government endeavored- to make unconvertible treas-

I In the usual gold clause obligation the obligor promises to pay the obligee the amount of the obligation "in gold coin of the United States of America of the standard of weight and fineness" existing as of the date of the obligation. A common variant is the gold clause in the United States' government obligations, which substitutes the words "of the present standard of value." Another common variation is to insert the words "of or equal to" before the words "the standard of weight and fineness." The obvious intent of the parties in stipulating for payment in gold coin of a certain weight and fineness is to provide against fluctuation in the value of the medium of payment. Butler v. Horwitz, 7 Wall. (U.S.) 258, I9 L. Ed. I49 (I869). See George Nebolsine, The Gold Clause in Private Contracts, 42 Yale L. Jour. ro5 I (r933).

2 It has been estimated that, of the $\$ 200,000,000,000$ public and private debt, approximately one half contains a gold clause in one form or other. Estimate of Interest Bearing Debt, 3 National Industrial Conference Board Bulletin (Feb. I5, I933); Irving Fisher, Booms and Depressions (1932), Iog.

On Jan. I, I934, the President issued a proclamation fixing the weight of the gold dollar at I55.2I grams, nine-tenths fine. This is $59.06+$ per cent of the former weight of 258 . Io grams, nine-tenths fine, as fixed by 3 I Stat. 45 ( 1900$)$, $3^{I}$ U.S.C.A. $\$ 3^{I} 4$ (I927). This means that approximately $\$ \mathrm{r} .69$ in the present currency represents the equivalent on a gold basis of a promise to pay $\$ \mathrm{r} .00$ in gold made before the Devaluation Proclamation. If the gold clause is construed as a promise to pay either the amount of gold that is contained in the number of dollars of the obligation, or the value thereof in terms of legal tender currency, the statute nullifying gold clauses in effect transfers about sixty-nine billion dollars from gold clause creditors to gold clause debtors. This, however, is not wholly inequitable since the gold clause creditor would get, under the statute, about the same real value (in terms of commodities) that he contemplated being repaid, due to the prevailing low price levels.

${ }^{3} 48$ Stat. II3 (I933), 3 I U.S.C.A. Supp. $\$ 82$ (I933). The retention of gold coin, gold bullion, and gold certificates was declared to be illegal by the Act of March 9, r933. H. R. No. 49r, 73 Cong. Pub. Acts No. I. The constitutionality of the act was sustained in Campbell v. Chase National Bank, I F. Supp. (D.C.N.Y. I933). By the Act of Jan. 30, I934, all gold coin and bullion (except for industrial purposes) is to be turned over to the United States Treasury to be formed into bars of such weight and fineness as the Secretary of the Treasury may direct.

4 x2 Stat. 345 (I862), 3I U.S.C.A. $\$ 45^{2}$ (1927). The character of the legal tender of the notes was necessary to insure their circulation because of the prevalent doubt as to the stability or solvency of the Union government. After the war Congress retired a portion of the notes; 
ury notes, "greenbacks," legal tender for all debts, public and private, except as payment for duties on imports and interest on the public debt.5 While the constitutionality of this legislation was still undecided, the Supreme Court in Bronson v. Rodes ${ }^{6}$ held that the Legal Tender Act did not apply to obligations

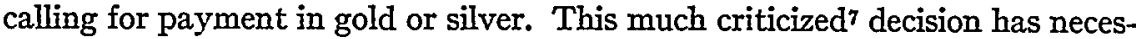
sitated express legislation nullifying the effect of gold clauses, since it overruled a long line of state court decisions holding that the Legal Tender Act required a holder of a gold clause obligation to accept the amount named in any legal tender currency. ${ }^{8}$ The court in the Bronson case reasoned that the Legal Tender Act did not include obligations calling for payment in specie within the classification "all debts," but rather applied only to promises to pay in money generally. 9 The court placed much weight on the supposed intention of the parties to contract for the delivery of gold or silver as a commodity, but this aspect of the case has been largely discarded. ${ }^{\text {Io }}$ The Bronson case did not decide, however,

approximately $\$ 346,000,000$ were left in circulation. 20 Stat. 87 (I878), 3I U.S.C.A. $\$ 404$ (I929). See Johnson, Constitutional Limitations and the Gold Standard, 67 U.S. L. Rev. 187, I88 (I933).

5 Cheang-Kee v. United States, 3 Wall. (U.S.) 320, I8 L. Ed. 72 (I866).

${ }_{7}^{6}$ Wall. (U.S.) 229, Ig L. Ed. I4I (I869).

7 See Hunt, Legal Tender, 67-Ir 7 .

${ }^{8}$ The state decisions before Bronson v. Rodes almost unanimously held that contracts calling for payment in gold, silver, or any other currency were debts within the purview of the Legal Tender Act and so could be satisfied by a tender of the nominal amount in any of the currencies designated by the Act. Whetstone v. Colley, 36 Ill. 328 (I865); Brown v. Welch, 26 Ind. II6 (I866); Riley, Exr. v. Sharp, I Bush (Ky.) 348 (I866); Galliano v. Leon Pierre \& Co., I8 La. Ann. Io (I866); Wood v. Bullens, 6 Allen (Mass.) 5 I6 (I863); Howe v. Nickerson, I4 Allen (Mass.) 400 (1867); Bucheggar v. Shultz, I3 Mich. 420 (I865); Appel v. Woltman, 38 Mo. 194 (x866); Rodes v. Bronson, 34 N.Y. 649 (I866); Legal Tender Cases, 52 Pa. 9 (r866); Mervine v. Sailor, 52 Pa. $x 8$ (I866); 29 L.R.A. 5x2 (I896); 84 A.L.R. I499 (I933). Most of the state decisions which denied the existence of Congress' power to provide that any legal tender money might be used to pay obligations calling for a particular kind of currency reasoned that the kind called for was to be treated as a commodity rather than money. Essex Co. v. Pacific Mills, $\mathrm{I}_{4}$ Allen (Mass.) 389 ( 1867 ).

The state courts after Bronson v. Rodes followed the United States Supreme Court's interpretation of the clause. Bower v. Darby, $x_{4}$ Fla. 202 (1872); McGoon v. Shirk, 54 MIl. 408 (I870); Morrow v. Rainey, 58 Ill. 357 (I87I); Chamberlin v. Blair, $5^{8}$ Ill. 385 (I87x); Belford v. Woodward, I58 Ill. I22, 4I N.E. ro97 (1895); Warren v. Franklin Ins. Co., I04 Mass. 518 (I870) ; Stark v. Coffin, I05 Mass. 328 (I870); Chrysler v. Renois, 43 N.Y. 209 (I870); Walkup v. Houston, 65 N.C. 501 (187 I); Phillips v. Dugan, 2r Ohio St. 466 (187x); Rankin v. Demott, 6r Pa, 263 (I869); Bobo v. Goss, I S.C. 262 (I8Io).

9 Hunt, Legal Tender, $67-\mathrm{rI} 7$, points out the inconsistency of the court in treating contracts providing for payment in a certain coin as contracts calling for a certain commodity and at the same time giving judgment in the coin called for. If it were a true commodity contract then the judgment debtor should be able to offer legal tender for damages, since the breach of a commodity contract creates a primary right only to collect money damages. It should be noted that at the time of the Bronson case gold coin was available, whereas it is not today.

so Thompson v. Butler, 95 U.S. 694, 24 L. Ed. 540 (1878); infra, n. 3 I. 
that a statute expressly including debts payable in gold was unconstitutional. ${ }^{\text {Ir }}$ It is significant that the same court which decided the Bronson case later declared the Legal Tender Act unconstitutional ${ }^{12}$ as applied to contracts made before its passage, and then, after two vacancies on the Court had been filled, reversed its former holding and sustained the validity of this legislation in the Legal Tender Cases. ${ }^{23}$ This decision did not, however, purport to overrule the Bronson case; and the court has often expressly reaffirmed the principle of that case. $^{x 4}$

A more realistic view of the parties' intention in inserting a gold clause in their agreement has been adopted by the House of Lords in a recent case, Feist v. Societe Intercommunale Belge D'Electricite, ${ }^{15}$ in which payment was to be made "in gold coin of the United Kingdom of or equal to the standard of weight and fineness existing on Sept. I, I928." Parliament had previously withdrawn gold from circulation, ${ }^{16}$ and in ${ }^{1} 928$ the power to issue inconvertible notes was restored to the Bank of England, ${ }^{17}$ and such notes were made legal tender. The Chancery Division and the Court of Appeal ${ }^{88}$ held that, despite the parties' intention to have payment in terms of gold coin, Parliament had intended that the payment of the nominal amount of the debt in legal tender bank notes was a discharge of the obligation. The House of Lords, however, decided that the legislation was not aimed at the amount of the debt but only at the types of currency which were legal tender; and that the parties contemplated that the obligor in satisfying the debt would pay in legal tender an amount sufficient to purchase the same amount of gold as the number of pounds loaned would have purchased at the time of the creation of the obligation.

The state courts before the decision in Bronson v. Rodes had uniformly held that a promise to pay in gold was no more than a promise to pay in legal tender,

II Legal Tender Cases, I2 Wall. (U.S.) 457, 20 L. Ed. 287 (I87I).

${ }^{22}$ Willard v. Tayloe, 8 Wall. (U.S.) 557, I9 L. Ed. 501 (1870); Hepburn v. Griswold, 8 Wall. (U.S.) 603, Ig L. Ed. $5 \mathrm{I}_{3}$ (I870).

${ }^{23}$ I2 Wall. (U.S.) 457,20 L. Ed. 287 (I87 I). The second Legal Tender Act, 20 Stat. 87 (I878), was sustained in Juilliard v. Greenman, x 10 U.S. 42I, 4 Sup. Ct. 122, 28 L. Ed. 204 (I884). Accord, Railroad Co. v. Johnson, ${ }_{5}$ Wall. (U.S.) I95, 21 L. Ed. I78 (I873); Dooley v. Smith, I3 Wall. (U.S.) 604, 20 L. Ed. 547 (I872).

${ }^{4}$ Thompson v. Riggs, 5 Wall. (U.S.) 663, I8 L. Ed. 704 (r867); Butler v. Horwitz, 7 Wall. (U.S.) 258 , I9 L. Ed. I49 (I869); Bronson v. Kimpton, 8 Wall. (U.S.) 444 , I9 L. Ed. 433 (1869); Trebilcock v. Wilson, 12 Wall. (U.S.) 687,20 L. Ed. 460 (I872); The Vaughan and Telegraph, $1_{4}$ Wall. (U.S.) 258, 20 L. Ed. 807 (I872); The Emily Souder, I7 Wall. (U.S.) 666, 2 I L. Ed. 683 (I873); Maryland v. Railroad Co., 22 Wall. (U.S.) ro5, 22 L. Ed. 7r3 (r874); Thompson v. Butler, 95 U.S. 694, 24 L. Ed. 540 (I878); Woodruff v. Mississippi, I62 U.S. 29 I, 16 Sup. Ct. 820, 40 L. Ed. 973 (I896); cf. Gregory v. Morris, 96 U.S. 6r9, 24 L. Ed. 740 (I878).

${ }^{\text {Is }} 5 \circ$ T.L.R. I43, I50 I.T.R. 5 I (I933); see Loboskey, The House of Lords on the Gold Clause, Its Significance to America, 43 Annalist 43 (I934).

${ }^{26}$ Gold Standard Act of 1925 .

17 Currency and Bank Notes Act.

${ }^{28} 49$ T.L.R. 344, I75 L.T. Jour. 226 (1933). 
because gold itself was nothing more than a particular type of legal tender. Hence payment in any kind of legal tender was a satisfactory discharge of the obligation. ${ }^{19}$ This would seem clearly inconsistent with the actual intent of the parties, and it is doubtful whether the United States Supreme Court would accept that view of the gold clause.

The Federal Constitution nowhere expressly authorizes Congress to nullify a stipulation by the parties that their obligation shall be discharged only by the payment of gold. But the validity of federal legislation does not depend exclusively on express grants. Power to legislate on a given subject may be deduced from a grouping of express powers, as was done in making notes legal tender, ${ }^{20}$ or by finding the power in question to be necessary and proper for the effective execution of other express powers, as was done in chartering national banks. ${ }^{2 I}$ Thus, if the court should adopt the view of gold clauses that prevailed in the state courts ${ }^{22}$ before Bronson v. Rodes, that a stipulation for payment in gold is nothing more than an indication that payment is to be made in one type of legal tender, the legislative direction that such obligations may be discharged by payment of legal tender currency is within the power of Congress. For Congress concededly has power to declare that gold coin is no longer legal tender; ${ }^{23}$ it is given plenary powers over the currency; and it can coin money and regulate the value thereof and borrow money on credit. ${ }^{24}$ From these express powers, the power to establish a national currency adequate for the needs of the country has been implied. ${ }^{25}$ Along with the power to make inconvertible notes legal tender,

19 Supra note 8.

${ }^{20}$ Legal Tender Cases, I2 Wall. (U.S.) $457,534,20 \mathrm{~L}$. Ed. 287 (187x). "And here it is to be observed it is not indispensable to the existence of any power claimed for the federal government that it can be found specified in the words of the constitution or clearly and directly traceable to some one of the specified powers. Its existence may be deduced fairly from more than one of the substantive powers expressly defined, or from them all combined. It is allowable to group together any number of them and infer from them all that the power claimed has been conferred."

This doctrine approaches an acceptance of the doctrine of inherent sovereign powers. If such powers did exist, a statute nullifying gold clauses might well be justified as a necessary means of effecting an essential economic relief; however, the doctrine has been rejected by the Supreme Court. Kansas v. Colorado, 206 U.S. 46,27 Sup. Ct. 655,5 I L. Ed. 956 (I9o7). I Willoughby, Constitution (2d ed. x929), 8r-82.

${ }^{2 x}$ McCulloch v. Maryland, 4 Wheat. (U.S.) $3 x 6,4$ L. Ed. 579 (I8Ig). As to the general nature of this process of analysis, see 3 Willoughby, The Constitutional Law of the United States (2d ed. 1929), Io66 Burdick, Law of the American Constitution (r933), 407. In this connection, Marshall's famous criteria of implied powers should be recalled: "Let the end be legitimate, let it be within the scope of the constitution, and all the means which are appropriate, which are plainly adapted to that end, which are not prohibited, but consistent with the letter and spirit of the constitution are constitutional." 4 Wheat. (U.S.) 3 II6, $42 I$.

${ }^{23}$ Supra note 8.

${ }^{23}$ Juilliard v. Greenman, IIO U.S. 42I, 4 Sup. Ct. I22, 28 L. Ed. 204 (I884).

24 U.S. Const., Art. r, $\$ 8$, cl. 5 .

${ }_{25}$ Note the language of the court in Veazie Bank v. Fenno, 8 Wall. (U.S.) 533,549 , 19 L. Ed. 482 (I869). "Having thus in the exercise of undisputed constitutional power undertaken to 
Congress can decrease the gold content of the dollar, ${ }_{2}^{26}$ prohibit the exporting of money from the country, ${ }^{27}$ tax state currency out of existence, ${ }^{28}$ and establish a national bank. ${ }^{29}$ And, if it is assumed that the parties in stipulating for payment in gold intended that the obligation might be discharged by payment in legal tender, no question of impairment of the obligation of contracts would seemingly arise.

If the Supreme Court holds (as is more probable) that the gold clause is inserted in contracts for the purpose of guarding against depreciation of paper currency, which is substantially the view expressed in past cases decided by the United States Supreme Court ${ }^{30}$ and is also the view recently adopted in the English courts, the power of Congress to refuse effect to such a safeguard is much less certain. On the other hand, a power to legislate on a given subject may be deduced from a grouping of express powers or may be implied as necessary and proper to the execution of express powers. Thus Congress has complete control of the currency system of the country. As an adjunct of this power to regulate the currency, Congress has the power to reduce the gold content of the paper dollar. But only to devaluate the dollar at a time like the present

provide a currency for the whole country, it can secure the benefit of it to the people by appropriate legislation. To this end Congress has denied the quality of legal tender to foreign coins, has provided against the imposition of counterfeit and base coin on the community. To the same end Congress may restrain, by suitable enactments, the circulation as money of any notes issued under its authority. Without this power, indeed, its attempt to secure a sound and uniform currency for the country would be futile." See also Juilliard v. Greenman, rro U.S. 42r, 448 Sup. Ct. I22, 28 L. Ed. 204 (I884), where the court said: "Under the power to borrow money on credit of the United States and to issue circulating notes for the money borrowed, its power to define the quality and force of these notes as currency is as broad as the like power over a melallic currency ander the power to coin money and regulate the value thereof. Under the two powers, taken together, Congress is authorized to establish a national currency, either in coin or in paper and to make the currency lawful money for all purposes, as regards the national government or the private individual." (Italics supplied.)

${ }^{26}$ While the power of Congress to devalue the gold dollar seems never to have been directly passed on by the Supreme Court, the language of the court in the Legal Tender Cases, 12 Wall. (U.S.) 457,20 L. Ed. 287 (I87x), and Juilliard v. Greenman, IIo U.S. 42I, 4 Sup. Ct. I22, 28 L. Ed. 204 ( 1884 ), indicates that it is indisputable. No case seems to have arisen contesting the validity the Act of June $28, x 834$, by which approximately six per cent was taken from the weight of each gold dollar.

${ }^{27}$ Ling Su Fan v. United States, 218 U.S. 302, 3r Sup. Ct. 2I, 54 L. Ed. 1049 (I9Io).

28 Veazie Bank v. Fenno, 8 Wall. (U.S.) 533, rg L. Ed. 482 (r869).

29 United States v. Fisher, 2 Cranch (U.S.) 358, 2 L. Ed. 304 (I805); McCulloch v. Maryland, 4 Wheat. (U.S.) 3I6, 4 L. Ed. 579 (I8I9); Gibbons v. Ogden, 9 Wheat. (U.S.) I, 6 L. Ed. 23 (I824).

${ }^{30}$ Decisions of the Supreme Court since the Bronson case show that it no longer relies on the argument that a promise to pay in gold is a contract for the delivery of a certain commodity. See Thompson v. Butler, 95 U.S. 694,24 L. Ed. 540 (1878), in which the court said that a contract to pay in gold or silver coin is a contract to pay money, and none the less so because it designates one of two kinds of legal tender; cf. Legal Tender Cases, 12 Wall. (U.S.) 457,20 L. Ed. 287 ( $187 x)$. 
would impose an unconscionable burden on gold clause debtors. ${ }^{3 \mathrm{r}}$ The decision by Congress as to the expedience of a measure providing for the devaluation of the dollar ${ }^{32}$ is not reviewable by the courts. ${ }^{33}$ Thus it would seem that, if Congress believes that the devaluation of the dollar would be ineffective unless gold clauses are nullified, the power to provide an adequate currency for the country may only be effectively exercised if it is accompanied by the power to nullify the gold clauses. ${ }^{34}$

Nullification of the effect of gold clauses is not thought to be essential to the existence of the power to devalue the dollar. If, however, the devaluation of the dollar would be so disastrous to the currency system of the country as to restrain Congress from passing such legislation while gold clauses are in operation, it would seem that the nullification of such clauses is necessary to the execution of the power to devalue the dollar. ${ }^{35}$

The argument that legislation nullifying gold clauses is unconstitutional as an impairment of contract in violation of the due process clause of the 5 th amendment would seem to be of little weight since it is clear from many decisions that Congress may impair the obligation of contract in the reasonable exercise of its powers..$^{36}$ If the gold clause in contracts constitutes an interference with

${ }^{3 x}$ Supra note 2. See also 7 F. Supp. I (D.C. Mo. 1934) where the court upholding the constitutionality of the statute nullifying gold clauses said, "So it is obvious, $I$ think, that the upholding of these so called gold clause contracts would vastly hurt, if not destroy business, and shake if not overturn the entire financial structure of this country. It would, I repeat, bankrupt well-nigh every railroad, every municipality, every road district, or similar instrumentality of state government and well-nigh every state in the Union, and since, in the financial crash of these debtor classes, the creditor classes, now urging the letter of their bonds, might well themselves go down in the common ruin, this situation as already suggested, should be avoided if it is legally possible within constitutional limits." Note the sympathetic attitude of the Supreme Court toward debtors in times of emergency. Home Building and Loan Ass. v. Blaisdell 290 U.S. 398 (I934).

${ }^{32}$ Act of Jan. 3r, I934.

${ }_{33}$ Juilliard v. Greenman, I IO U.S. 42I, 4 Sup. Ct. I22, 28 L. Ed. 204 (I884). Thayer, Legal Essays, go, states: "If there be any exigency as, for example, that of war, in which the government may make its own notes, or any other, legal tender, it seems purely a legislative question when such exigency has in point of fact arisen. This was the unanimous opinion on Juilliard $v$. Greenman."

34 Supra note 25.

${ }^{35}$ Supra note 25.

${ }^{36}$ In Juilliard v. Greenman, Iro U.S. 42 r, 4 Sup. Ct. I22, 28 I. Ed. 204 (1884), Mr. Justice Gray said: "If, upon a just and fair interpretation of the whole constitution, a particular power or authority appears vested in Congress, it is no constitutional objection to its existence or to its exercise, that the property or the contracts of individuals may be incidentally affected." In the Legal Tender Cases, 12 Wall. (U.S.) 457, 550, 20 L. Ed. 287 (I87I), the court said, "It is then clear that the power of Congress may be exerted, though the effect of such exertion may be in one case to annul, and in the other case to impair the obligations of contracts. And it is no sufficient answer to this to say it is true only where the powers exerted were expressly granted." It is significant that the court in this case avoided a finding of impairment by holding that money contracts are made subject to the regulation of currency.

A case involving deprivation of property in the exercise of the coinage power is ling Su Fan v. United States, 2 I8 U.S. 302, 3 I Sup. Ct. 21, 54 L. Ed. ro49 (I9IO). The court held the power 
the ability to establish for the country, in these times, an adequate currency system, then it may well be urged that the power to nullify the gold clause is necessary to the effective exercise of the money powers of Congress. ${ }^{37}$ The treatment afforded statutes regulating interstate commerce, ${ }^{38}$ bankruptcy, ${ }^{39}$

to coin money included the power to prevent its outflow from the country of its origin, and did not constitute such an arbitrary or unreasonable interference with private rights as to be lacking in due process. The court also declared that the wisdom of the legislation does not affect the question of Congress' power. 3 Willoughby, The Constitutional Law of the United States, (2d ed. I929), I857.

In Knox v. Lee, I2 Wall. (U.S.) 457,55 I, 20 L. Ed. 287 (I87I), the court said, "As in a state of civil society, property of a citizen or subject is ownership subject to the lawful demands of the sovereign, so contracts must be understood as made in reference to the possible exercise of rightful authority of the government, and no obligation of a contract can extend to the defeat of legitimate government authority."

${ }^{37}$ See Willard, Post, Power of Congress to Nullify Gold Clauses, 46 Harv. L. Rev. I225 (r933); see also Norman v. Baltimore \& Ohio R.R., 265 N.Y. 37, I9I N.E. 726 (I934), in which Chief Justice Pound in sustaining the statute nullifying gold clause stated: "To subordinate the exercise of the Federal authority to the continuing operation of previous contracts would be to place to this extent the power to coin money and regulate its value in the hands of private individuals and thus to impair the sovereign power delegated to the national government."

${ }^{38}$ Addyston Pipe \& Steel Co. v. United States, $x 75$ U.S. 2rx, 228, 20 Sup. Ct. 96, 44 L. Ed. I36 (I899): "We do not assent to the correctness of the proposition that the constitutional guaranty of liberty to individuals to enter into private contracts limits the power of Congress and prevents it from legislating upon the subject of contracts relating to interstate commerce. .... Congress ... . may enact such legislation as shall declare void and prohibit the performance of any contracts between individuals or corporations where the natural and direct effect of such contracts will be, when carried out, to directly .... regulate [sic] to any substantial extent interstate commerce."

In Atlantic Coast Line R.R. Co. v. Riverside Mills, 219 U.S. I86, 3r Sup. Ct. I64, 55 L. Ed I67 (Igrx), the court admitted that the effect of its holding was to deny to the initial carrier a freedom to enter into a contract limiting its liability, but said, "It is obvious from many decisions of this court, that there is no such thing as absolute freedom of contract. Contracts which contravene public policy cannot lawfully be made at all; and the power to make contracts may in all cases be regulated as to form, as to validity, and as to third persons. The power of governinent extends to the denial of liberty to contract to the extent of forbidding or regulating every contract which is reasonably calculated to injuriously affect the public interest.

"Having the express power to make rules for conduct of commerce among the states, the range of congressional direction as to regulations best adapted to remedy a practice found hurtful is a wide one. If the regulating act be one directly applicable to such commerce, not obnoxious to any provision of the constitution, and reasonably adapted to the purpose by reason of legitimate relation between such commerce and the rule provided, the question of power is foreclosed." (219 U.S. 202).

See also Louisville \& Nashville R.R. Co. v. Mottley, 219 U.S. 467, 3I Sup. Ct. 265, 55 L. Ed. 297 (rgrr); Houston, E. \& W. Tex. Ry. v. United States, 234 U.S. 342, 34 Sup. Ct. 833, 57 L. Ed. r34I (rgI4); New York v. United States, 257 U.S. 59I, 42 Sup. Ct. 234, 66 L. Ed. 385 (I922); Stafford v. Wallace, 258 U.S. 495, 42 Sup. Ct. 397, 66 I. Ed. 735 (I932); Hill v. Wallace, 259 U.S. 344, 42 Sup. Ct. 453, 66 L. Ed. 822 (x922); United Mine Workers of America v. Coronado Coal Co., 259 U.S. 344, 42 Sup. Ct. 570, 66 L. Ed. 675 (I922); C., B. \& Q. R.R. Co. v. McGuire, 2rg U.S. 549, 3 I Sup. Ct. 259, 55 L. Ed. 328 (r9II); Philadelphia, B. \& W. R.R. Co. v. Schubert, 224 U.S. 603,32 Sup. Ct. 589, 56 L. Ed. 9II (IgI2).

${ }^{39}$ Hanover National Bank v. Moyses, I86 U.S. r8r, 22 Sup. Ct. 857, 46 L. Ed. III3 (Ig02). 
tariffs, embargoes and requisitions $4^{\circ}$ would indicate that the legislation in question will not be considered an "impairment" within the meaning of the constitutional prohibition of the due process clause.4r

The present emergency, moreover, may have a persuasive effect on any determination of constitutionality. While it is said that emergency will not create a power, it will provide an excuse for the exercise of power which could not otherwise be exercised, ${ }^{2}$ and will make legislation, unreasonable in normal times, reasonable in the light of present conditions.

40 Buttfield v. Stranahan, I92 U.S. 470, 24 Sup. Ct. 349 (I883); Armoúr Packing Co. v. United States, 209 U.S. 56, 28 Sup. Ct. 428, 52 L. Ed. 68I (Ig08); Norwegian Products Co. v. United States, 288 U.S. 294, 53 Sup. Ct. 35, 77 L. Ed. 796 (I933).

${ }_{41}$ See Collier, Gold Contracts and Legislative Power, 2 Geo. Wash. L. Rev. 303, 334 (I934). The author compares the proviso of section I of Article I, of the U.S. Constitution which prohibits the states from passing laws impairing obligation of contracts with the due process clause of the $5^{\text {th }}$ amendment and points out that the two clauses are obviously not co-extensive although they may sometimes in particular situations have a similar restrictive effect.

42 Block v. Hirsh, 256 U.S. $x_{35}$ 4 4 Sup. Ct. 458, 65 L. Ed. 865; Edgar A. Levy Leasing Co. v. Siegel, 258 U.S. 242, 42 Sup. Ct. 289, 66 L. Ed. 595 (I922); Marcus Brown Holding Co. v. Feldman, 256 U.S. 170, 4I Sup. Ct. 465, 65 L. Ed. 877 (I92I); Chastleton Corp. v. Sinclair, 264 U.S. 543, 44 Sup. Ct. 405, 68 L. Ed. 84I (1924). In the celebrated decision of Wilson v. New, 243 U.S. 332, 37 Sup. Ct. 298, 6r L. Ed. 755 (IgI 7), Chief Justice White upheld the power of Congress, when an emergency confronted the government, to halt a threatened strike of railway trainmen by fixing their wages and hours of work. See also Coppage v. Kansas, ${ }^{2} 6$ U.S. r, 35 Sup. Ct. 240, 59 L. Ed. 44I (r9I5); Adair v. United States, 208 U.S. r6r, 28 Sup. Ct. 277, 52 L. Ed. 436 (Igo8); cf. Bailey v. Alabama, 229 U.S. 219, 3r Sup. Ct. I45, 55 L. Ed. I9 I (IgrI); Clyatt v. United States, I97 U.S. 207, 25 Sup. Ct. 429, 49 L. Ed. 726 (I905). See Home Building \& Loan Association v. Blaisdell, 290 U.S. 398, 54 Sup. Ct. 23I (I934); I Univ. Chi. I. Rev. 639 (1934). 